\section{Health assembly rebuffs Taiwan's bid for 'observer' status}

\section{Declan Butler}

As officials from 192 countries gathered in Geneva this week for the annual meeting of the World Health Assembly, Chien-Jen Chen, Taiwan's minister of health, was left knocking on the door.

Taiwan is not recognized by the World Health Organization (WHO) - its access to $\mathrm{WHO}$ people and programmes is at the discretion of China. But Chen's government wants to be given 'observer' status, arguing that its scientists are currently being shut out of global investigations into severe acute respiratory syndrome (SARS) and other diseases (see Nature 422, 652; 2003).

In the event, Taiwan's bid did not get very far. The assembly's general committee decided not to put it on the agenda. The country's eighth unsuccessful bid was rejected after what one WHO official describes as "lengthy discussions", adding that Taiwan did secure strong US and Japanese backing for the first time.

China does not recognize the government of Taiwan. The United Nations, which admitted China in 1972, also does not consider Taiwan a state, which prevents Taiwan from becoming a full member of WHO. But the World Health Assembly, which serves as WHO's main decision-making body, could grant Taiwan observer status, if it so wished.

Chen says that the bid "tried to avoid one-China politics", and describes it as Taiwan's "humble request to help realize health for all". But in a report by China's official Xinhua news agency on Monday, Gao Qiang, the Chinese vice-minister of health, claims Taiwan "has no difficulties in getting information from WHO and carrying out technical exchanges with it". Taiwan's true purpose, Qiang is quoted as saying, is to "politicize the health issue and to internationalize the Taiwan issue".

Qiang adds that China has permitted Taiwan experts to attend WHO meetings. But Chen counters that they were invited to SARS meetings on the basis of their expertise and that Chinese interference delayed the invitations.

According to a WHO official, many of its members, including most European countries, do not want to grant Taiwan observer status in case this is seen a step towards diplomatic recognition. But Chen says he will be back next year to press the case for the admission of a country that, with 23 million people, has a larger population than three-quarters of the WHO member states.

\title{
Panel slated for leniency over study of NIH consulting roles
}

\section{Erika Check, Washington}

A special panel that investigated conflict-ofinterest practices at the National Institutes of Health (NIH) got a chilly reception on Capitol Hill last week. Law-makers and their staffs made it clear that the biomedical agency will be dogged by the issue for many months to come.

The 'blue ribbon panel' was chaired by Bruce Alberts, president of the National Academy of Sciences, and Norman Augustine, chairman of the defence contractor Lockheed Martin. The pair joined NIH director Elias Zerhouni to brief law-makers at a hearing on 12 May. This was just six days after the panel released its report recommending changes to the way that the NIH manages the consulting partnerships its employees have with private companies and academic institutions (see Nature 429, 119; 2004).

But members of Congress at the hearing said the panel had not gone nearly far enough, and that they would continue to probe the NIH's practices. "It is clear that some NIH scientists are very close to the line or have crossed the line," said James Greenwood (Republican, Pennsylvania), chairman of the investigations subcommittee of the House of Representatives' Committee on Energy and Commerce. "The blue ribbon panel seems to handle conflict-of-interest issues gently."

And the chairman of the full energy and commerce committee, Joe Barton (Republican, Texas), accused the NIH and its parent agency, the Department of Health and Human Services, of stalling Greenwood's investigation. "We have found the NIH to be less than cooperative," Barton said. "Your officials can be cooperative cooperatively, or we're going to make them cooperative coercively," Barton told Zerhouni.

One veteran congressional staff member says the conflict-of-interest issue has put "a huge black mark" against the NIH. The agency has recently been favoured by lawmakers of both parties, who doubled its budget from 1998 to 2003 . Now, the staff member says, "the bloom is off the rose at the NIH".

At the hearing, law-makers appeared incensed that NIH scientists had been engaging in practices that they considered to be ethically indefensible while the agency was receiving huge budget increases. According to congressional staff and lobbyists, some on Capitol Hill feel personally betrayed by the revelations about the NIH's outside consulting deals, which first appeared in the Los Angeles Timeslast December.

And although congressional committees steered clear of overseeing the NIH during the period of its budget doubling, their approach is now changing dramatically. At the 12 May hearing, Barton indicated that he would try this year to pass a law called a "reauthorization", which will spell out policies and procedures for the NIH. Such bills are supposed to be passed every five years or so, but Congress has not reauthorized the agency since 1993.

"You have got members of Congress who were not really engaged in oversight who now want to step up to the plate," says one NIH advocate. Greenwood's subcommittee was due to hold a second hearing on the issue on 18 May, six days after the first one.

Biomedical lobbyists predict that the conflict-of-interest issue will follow the NIH for a while. One said that it will turn into a "summer mini-series", playing out in a string of potentially embarrassing hearings.

That could stifle any effort to increase the NIH's 2005 budget above the $2.6 \%$ increase proposed for the agency by the president George W. Bush in February. NIH supporters may plead with law-makers to give the agency an $8-10 \%$ budget increase, but they will get nowhere fast, the lobbyists say. "This issue gives a handy excuse to folks in Congress who are saying: we just doubled your budget, how can you come back asking for more?" says one experienced NIH supporter. "This adds to what is shaping up to be a very bad environment for NIH advocacy." 